\title{
Competing Paradigms? The Use of DNA Powers in Youth Justice
}

\author{
Liz Campbell and Nessa Lynch
}

\begin{abstract}
DNA is an important tool for criminal investigations and prosecutions. There has been considerable comment on its collection and retention from adult suspects and convicted persons, but little analysis of the particular situation of young people in the youth justice system. This article considers the competing paradigms at play when young persons' DNA is collected and stored. The tensions between expanded DNA powers and norms of youth justice such as reintegration and best interests are considered as well as the implications for the young person's rights.
\end{abstract}

Keywords: DNA, youth justice, comparative, policy transfer, human rights

\section{Introduction}

Collecting deoxyribonucleic acid (DNA) from crime scenes and individuals is now regarded as a critical element of effective criminal investigation and prosecution. Numerous benefits are said to accrue from the gathering and comparison of DNA evidence: suspects may be speedily identified, innocent parties ruled out, the wrongfully convicted exonerated and some would-be criminal actors deterred. Retention of DNA in state controlled databases allows for speculative searching to identify subsequent offending and to provide leads for unsolved crimes. The collection and retention of convicted adults' DNA has been held by European and US courts to be a proportionate incursion on human rights given the need to tackle crime effectively, although the law relating to un-convicted persons is more contentious (Campbell, 2010a). The application of DNA powers to young people in the youth justice system has received less attention.

This article considers the application and expansion of DNA powers in the youth justice system, and identifies the 'competing paradigms' at play. New Zealand and Scotland, often cited as having progressive and sensitive approaches to youth justice, are used to illustrate the tension between the perceived need for expanded powers of investigation and prosecution of crime and the rights and interests of young people. ${ }^{2}$ Both jurisdictions are recognised for their established emphasis on diversionary and non-stigmatising processes 
in youth justice but more recently, are experiencing broader trends away from a rightsoriented paradigm towards a more populist and punitive model. This article examines the recent expansion of DNA powers in both countries which illustrates a comparable trajectory away from conventional youth justice precepts. It assesses the safeguards, if any, that have been introduced to mitigate this 'ratcheting up' of crime control, which is particularly problematic in the context of young people. In doing so, we draw on our respective work on DNA and human rights (Campbell, 2011; 2010a; 2010b; 2010c) and the rights of young people in the youth justice system (Lynch, 2007; 2008; 2010a; 2010b). Our analysis of legislative developments has a wider application as many jurisdictions have adopted elements of the New Zealand and Scottish approaches to youth justice, and can also contribute to a wider discussion about compliance with international standards for youth justice in the context of DNA collection and storage.

\section{From Progressive to Punitive Paradigms?}

New Zealand and Scotland are recognised as having distinctive approaches to youth offending. The attributes of the 'New Zealand model': diversion, restorativeness, cultural flexibility, reintegration and decarceration have been highly influential on other jurisdictions (Morris and Maxwell, 2001; Muncie, 2005). New Zealand is unusual in having a sharp contrast between the progressive youth justice system and the punitive and populist adult system (Pratt and Clark, 2005), and amongst similar jurisdictions (particularly England and Wales) in resisting the 'punitive turn' (Goldson, 2002) in youth justice (Muncie, 2008). Similarly, Scotland has long had a distinctive approach to youth justice, especially when compared with the tactics adopted in England and Wales (McAra, 2008a; 2008b, Goldson, 2000). Most young people who come to the attention of the police for suspected criminal behaviour are dealt with by the informal (McDiarmid, 2001) lay Children's Hearing System (CHS) on the premise that young people involved in offending behaviour or who are victims of abuse or neglect should be treated in the same system according to their needs (Kilbrandon, 1964). This distinctive approach embodies the welfare principle and presupposes that any intervention must be in the best interests of the young person. 
Recent developments in both jurisdictions indicate a shift away from such traditional norms and premises, to a more politicised and punitive means of addressing problematic behaviour and youth offending. In New Zealand, the youth justice system was a central issue of the centre-right National Party's successful election campaign in 2008 (Key, 2008a). New legislation, the Children, Young Persons and Their Families (Youth Court Jurisdiction and Orders) Act 2010, reshapes the youth justice system (Lynch, 2010b; 2010c). Increased punitiveness is evident, particularly in the new power to prosecute 12 and 13 year old serious and persistent offenders rather than the previous welfare-based approach (Lynch, 2010c). An increase of the net of control is apparent in the expansion of existing Youth Court orders, and new approaches such as compulsory parenting education programmes and the strongly symbolic (Simon, 1995) 'military style activity camps'. The New Zealand youth justice system is now catching up with the adult criminal justice system which has in the last two decades been characterised by penal populism and an ever increasing prison population (Pratt and Clark, 2008). In Scotland, a similar trend to a more risk-oriented, managerial and punitive logic is evident in s. 16 (5) of the Children (Scotland) Act 1995 which allows the principle of best interests to be overruled in cases where the young person is considered to pose a risk of serious harm to others. The introduction of anti-social behaviour orders for young persons aged between 12 and 15, demonstrates a shift to a more populist and punitive ethos (Anti-social Behaviour (Scotland) Act 2004; Croall, 2005; and Piancentini and Walters, 2006). To a lesser extent, the trajectory of Scottish youth policy parallels that in New Zealand, driven by the co-opting of crime control by the Scottish Parliament as a means of building political capacity (McAra 2008a; 2008b).

Thus, while both jurisdictions retain a statutory imperative to divert young people from prosecution and custody, increased punitiveness is evident, particularly at the edges of the system. As we emphasise here, the expansion of DNA powers is symptomatic of this 'layering' of populist crime control measures onto established youth justice systems.

\section{The Use of DNA in Criminal Investigations}


Before considering the particular issues which expanded DNA powers pose for the rights and interests of young people, it is essential to discuss how DNA is used in criminal investigations. The genetic material in human DNA determines physical characteristics and traits, genetic disorders, susceptibility to disease and ethnic origin. An individual's DNA is unique (except in the case of identical twins) and is inherited from both one's parents. A DNA sample contains a range of intimate personal and family information. In contrast, a DNA profile, generated from a sample, is a set of identifying characteristics from regions of DNA that are not known to provide for any physical characteristics or medical conditions of the person. It consists of a list of numbers based on specific areas of DNA known as short tandem repeats and a gender indicator and thus may only be read and interpreted with the aid of technology (Parliamentary Office of Science and Technology, 2006). While profiles are computerised, they still contain 'substantial amounts of unique personal data' (S and Marper v United Kingdom (2009) 48 EHRR 50 [73]-[76]) including information about familial relationships and ethnic origin.

The use of DNA evidence is now widespread in criminal investigations and prosecution. The primary New Zealand legislation is the Criminal Investigations Bodily Samples Act 1995 (CIBS Act) which has been regularly amended since enactment. In the 2009/2010 reporting year, 12,089 samples were taken from suspects and volunteers, while 1948 identifications were made from crime scene DNA (New Zealand Police, 2010). The CIBS Act provides for a national DNA database on which DNA profiles from voluntary and compelled samples may be stored. As of the end of December 2010, there were approximately 115,500 profiles on the database (Personal Communication from ESR, January 2011). Scotland has a separate legal regime to the rest of the UK for DNA collection and retention and has its own DNA database, established in 1995 and operated by the Police Forensic Science Laboratory Dundee. Profiles derived from these DNA samples are exported to the UK-wide National DNA Database, and thus may be checked against those collected from persons in England, Wales and Northern Ireland (Johnson and Williams, 2004). This arrangement is not reciprocated. On 31 December 2007, the number of profiles from individuals on the DNA Database was 225,534 (Scottish Government, 2008). Between the dates of 1 January 2007 and 1 February 2010, 2,424 DNA samples were retained from those who have been 
prosecuted but not convicted for a relevant sexual or violent offence under section 18A of the Criminal Procedure (Scotland) Act 1995 (MacAskill, 2010).

\section{The Expansion of DNA Powers}

It is in the contexts of shifting attitudes to youth justice and increasing use of DNA evidence that recent changes have been made in both New Zealand and Scotland to how and when young persons' DNA may be collected and retained. It is notable that while policy transfer per se may not be discerned necessarily, which would denote purposeful imitative activity, equivalent trends are evident through a process of policy diffusion or convergence (Jones and Newburn, 2002). Thus, analysis of these jurisdictions contributes to a wider discussion about the appropriate use of DNA powers in youth justice systems.

\section{The collection of DNA}

In Scotland, the law relating to DNA collection is contained in the Criminal Procedure (Scotland) Act 1995, the enactment of which coincided with the establishment of the Scottish DNA database. A young person, akin to an adult, may be detained in a police station or other premises for up to six hours when he or she is suspected of having committed an offence (Criminal Procedure (Scotland) Act 1995, s.14(1)), and a constable may collect bodily samples from such an arrestee or detainee when the offence is punishable by imprisonment (Criminal Procedure (Scotland) Act 1995, s.18). Scientific advances mean that DNA is now collected from mouth swabs rather than requiring a blood test, and akin to the rest of the UK, such swabbing does not require consent. By contrast, until very recently, New Zealand had a conservative and sensitive approach to the collection of DNA from young people. Samples could be collected pursuant to a judicial order only, or with joint informed consent by the young person and his or her parent with more restrictions for those aged ten-13 years (Ministry of Justice, 2009). The approach showed an understanding of the vulnerability of young people during police investigation, and a cognisance of the invasiveness of DNA sampling and the importance of privacy rights (Redmayne, 1995; Campbell, 2010a). However, the Criminal Investigations (Bodily Samples) Amendment Act 2009 now enables a constable to require a young person to provide a 
bodily sample if the young person has been arrested or a police officer has good cause to suspect that he or she has committed a relevant offence (by 2012 this will include all imprisonable offences akin to Scotland) and intends to bring proceedings by way of a summons (s. $24(\mathrm{k}))$. The rationale for the new regime is clearly crime control: that DNA is a 'modern day fingerprint' which 'assist[s] Police to solve more crime by having more identified DNA profiles available to match against the increasing number of DNA samples obtained from unsolved crimes' (Ministry of Justice, 2009). The extension of police powers in New Zealand to acquire compulsorily DNA samples from young people at the time of apprehension is a radical departure from the previous regime, and mirrors extant policy in Scotland. The expansion to collection at time of arrest, and the expansion of the offence threshold will lead to considerably more samples being taken from young people. As we develop more fully below, this expansion of police powers of DNA collection from young people is problematic in terms of bodily integrity, appropriate police powers, and nondiscrimination, and is symptomatic of a largely welfare-oriented logic being subsumed by crime control demands.

Young people are particularly vulnerable when in police custody. They are prone to hurried or false admissions of guilt and are easily suggestible (Brookman and Pierpoint, 2003). The collection of a bodily sample is a significant intrusion to bodily integrity, particularly when collection is non-consensual or where reasonable force is used to collect the sample. Cram and Walker $(1990,486-7)$ have noted that 'the prospect of force being used by the police to keep a suspect still and to hold his lips open whilst his mouth lining is scraped does seem to be an extremely intrusive search' and this is particularly pertinent in the context of young people. As noted, the former New Zealand regime recognised the vulnerability of young people by providing for strict independent oversight in the form of judicial authorisation of compelled sampling of DNA or joint informed consent by the young person and his or her parent. However, current policy evidences a significant shift from this line of thought, to a model of sample collection which pays little regard to the vulnerability of young people. Both jurisdictions now permit collection from young people in custody pursuant only to the discretion of a police officer. In Scotland, Inspector approval of bodily sampling is required only where force is needed to obtain the sample (Criminal Procedure (Scotland) Act 1995, s. 
18(6)A). However, the consent of the young person or his or her parent is not required to gather a sample from which DNA may be gleaned. Similarly, the recently amended New Zealand legislation allows a constable to require a young person to provide a bodily sample (s. 24(k), CIBS Act).

What can be done to take account of the young person's immaturity (Steinberg and Scott, 2003) and vulnerability when DNA is to be collected in police custody? A wealth of procedures has developed to mitigate the vulnerability of young people during interviewing and questioning by the police. These include provision for the attendance of supporting adults and the use of age appropriate language, built on traditional protections for the accused such as legal advice and the right to silence (Kemp, et al, 2011). A similar approach should be followed in this instance. Both jurisdictions allow for the young person to have legal advice and parental support (s. 15 (4), Criminal Procedure (Scotland) Act); s. 8; 50; 50(A) CIBS Act) and the New Zealand legislation has requirements that the scheme of collection and possible retention is explained to the young person in a language he or she can understand (s. 6, s. 24(n), CIBS Act). Of course, parental attendance is no guarantee that the rights and interests of the young person are safeguarded, and sometimes parents can act to the detriment of their young person (Quinn and Jackson, 2007). In neither jurisdiction is there provision for independent oversight of the Police decision to take the DNA sample, and this is problematic in light of the vulnerability of young people in the context of the pre-trial process.

\section{Retention of young people's DNA}

While collection and retention of DNA overlap in respect of their consequences, retention raises some different issues, particularly labelling, reintegration and non-discrimination. In New Zealand, samples taken by the police may be converted into DNA profiles which may be stored on the National DNA Database if the person is convicted (which in this context includes young people whose offence has been 'proved' before the Youth Court, s. 2(1), CIBS Act). Until recently, the DNA of young people could only be collected under strict conditions, and so there have been very small numbers of profiles stored. Indeed, from 2000 - 2008, just two profiles from ten-13 year olds were loaded onto the database. For 
14- 16 year olds, small numbers of profiles were obtained by request at less than ten per year, but the number of profiles obtained by judicial compulsion order increased from 90 per year in 2000 to 213 in 2008 (Personal communication from New Zealand Police, 2010). The retention period for profiles on the database has recently been expanded significantly (s. 26(A)(4), CIBS Act). Now, if the offence is proved and the Youth Court makes an order under section 283 of the CYPF Act (this includes supervision with residence, mentoring, supervision with activity, etc.), a profile may be retained on the database for ten years. Importantly, the regularly used section 282, CYPF Act order (which is an absolute discharge - meaning that the young person has a clean record) can be the basis of retention of a profile for four years.

As noted, there is a presumption in Scotland that criminal proceedings should not be taken against a young person, unless his or her circumstances, the seriousness of the offence and the available evidence suggest that a criminal trial should be held (s. 42(1), Criminal Procedure (Scotland) Act 1995). Where a young person is convicted, his or her DNA may be retained indefinitely, as is the case for adults. Retention of DNA samples is allowed also after prosecution when it does not lead to conviction in relation to certain sexual or violent offences (s. 18A, as inserted by the Police, Public Order and Criminal Justice (Scotland) Act 2006). In the latter context, the destruction date is three years following the conclusion of proceedings and a sheriff may extend this for no more than two years (s. 18A(4), Criminal Procedure (Scotland) Act 1995) but nothing prevents recurring police applications to amend further this date. Given that the age of criminal responsibility in Scotland is eight (however the Criminal Justice and Licensing (Scotland) Act 2010 precludes the prosecution of anyone under the age of twelve (s. 41A, Criminal Procedure (Scotland) Act 1995), a not insignificant number of young people have had DNA collected. On 31 March 2009, there were 33 profiles of children aged under ten on the NDNAD taken by Scottish forces (National Policing Improvement Agency, 2009: 21). Moreover, one profile of a Scottish eight year old was held on the NDNAD on 31 July 2010 (National Policing Improvement Agency, 2009: 21). Retention is permitted only if proceedings have been instituted. Until recent legislative amendment, the Scottish State could not retain the sample of any young person dealt with by the welfare based CHS, even if he or she admitted guilt or if a sheriff 
found the grounds of referral to be substantiated. Only if a young person were dealt with by the criminal courts could a DNA sample be stored. A review of the law governing police acquisition and retention of forensic data in Scotland recommended that young people who accept or are found by a Sheriff to have committed a relevant sexual or violent offence (excluding assault but including serious assault) should be subject to the same DNA collection and retention regime as adults (Fraser, 2008; Scottish Government, 2009 and Campbell: 2010b). In other words, permanent DNA retention was favoured. In reaching its conclusion the Report drew on the likely numbers of young people involved, the seriousness of the relevant offences, the fact that there is either an acceptance of culpability on the part of the young person or an independent determination of responsibility by a Sheriff, and the need for public protection (Fraser, 2008: 17). The Criminal Justice and Licensing Act 2010 now permits the retention of DNA samples collected from young people who are not subsequently prosecuted but who are dealt with through the CHS (s. 80). Retention is for three years, with the possibility of extensions of two year blocks with approval from the Sheriff Court. The young person must accept the ground of referral along with his or her parent/guardian, or a sheriff must find the ground of referral to the CHS to be established.

The expanded retention of DNA in the context of youth justice raises questions about the rights of vulnerable young people. This is particularly pertinent when DNA powers are predicated on admissions made in informal processes. In the court-based adversarial system, there is an understanding that when an individual is convicted the standard of proof has been satisfied, through adversarial hearing or through plea of guilty, resulting in the person accepting or being attributed legal responsibility for the particular offence. However, the core precept on which the youth justice processes in New Zealand and Scotland are based is of diversion from the formal structures and strictures of the criminal justice process. The aim is to dispose of the majority of youth apprehensions (even serious offences) without recourse to prosecution, or at least, to conviction. Through processes like the FGC and the CHS, both systems seek to encourage early admission of the offence and precipitate frank discussion about offending so as to promote reintegration, corralled by the protection of the welfare of the young person. Defended hearings, and thus proof 
through the normal adversarial process, are rare. It is acknowledged that such diversionary processes are firmly in line with international standards for youth justice (Committee on the Rights of the Child, 2007), but may raise some issues when these processes are used as the basis for DNA retention.

Scotland (akin to the rest of the UK) allows DNA retention, even when the young person has not been convicted or even prosecuted. Where a young person comes to attention of the Scottish police, and officers have reasonable cause to believe that compulsory measures of supervision may be required, they have a duty to pass that information to the Reporter (Children (Scotland) Act 1995, s.53) who will decide if he or she needs to be referred to a Children's Hearing (McAra and McVie 2007: 327). A young person who has been referred to the CHS on offence grounds but does not accept the grounds may be further referred to a sheriff to determine if there is sufficient evidence to support the allegation. If the sheriff finds the grounds to be substantiated, another hearing is held to decide on supervision. Thus, DNA retention in Scotland can be predicated on a mere admission by the young person. By contrast, New Zealand does not allow retention of young people's DNA unless the offence has been 'proved' in the Youth Court. Nevertheless, New Zealand has a very unusual method of 'proving' the offence. Apart from the rare cases where the young person opts for a defended hearing, offences are proved through an admission at the FGC which is then noted on the record by the Youth Court Judge at a later hearing. There is conflicting case law as to whether this satisfies the presumption of innocence and there is evidence of deficiencies in practice, particularly in the young person understanding the difference in law between agreeing with the summary of facts and taking legal responsibility for an offence (Lynch, 2007).

Thus, when an admission made in an informal process is used to support the retention of DNA, it is crucial to ensure that the admission is sound, voluntary, and supported by evidence. Bearing in mind that the clientele of the youth justice system are invariably disadvantaged and less educated than non-offending young people (McLaren, 2002), there is a responsibility to ensure that young people understand the process and consequences of 
making admissions, including in particular the effects on genetic privacy of DNA retention. Legal or other independent advice should be available to the young person.

\section{Competing Paradigms}

As outlined, the approach towards DNA collection and retention in both jurisdictions is expanding, drawing on the influence of the remarkably broad system of DNA collection and retention in England and Wales (though this is to change with the enactment of the Protection of Freedoms Bill). There, a non-intimate sample ${ }^{4}$ may be taken without consent from a person who has been charged with, informed that he will be reported for, or convicted of a recordable offence (Criminal Justice and Public Order Act 1994 s. 55, as amended by the Criminal Justice Act 2003 s. 10) ${ }^{5}$ and indefinite retention of samples is permitted (Police and Criminal Evidence Act, s. 64(1)A, as inserted by the Criminal Justice and Police Act 2001). As a result, by July 2010, 5,412,776 people were included on the database, 101,194 aged 15 years and younger, and 181,137 aged 16 or 17 (National Policing Improvement Agency, 2010). Concern about the disproportionality of the English law in terms of its breadth and duration was articulated by the Nuffield Council on Bioethics (2007: [4.17], [4.23]) and such disquiet was translated into robust legal criticism in the European Court of Human Rights decision in $S$ and Marper $v$ United Kingdom which found the 'blanket and indiscriminate' retention of DNA to breach Article 8 of the ECHR which protects the right to privacy ((2009) 48 EHRR 50 [119]). Notably, the Grand Chamber of the ECtHR emphasised specifically the Scottish model as preferable and indeed the Scottish system is now heralded as the prototype for the rest of the United Kingdom ([109]; Campbell, 2010c) which is implementing this by means of the Protection of Freedoms Bill. 6

Notwithstanding the comparatively moderated form of DNA collection and retention in the jurisdictions under discussion, the expansion of DNA powers encapsulates neatly the acute tension between the competing paradigms and demands of youth justice in a domestic and international sense. The principles of the best interests of the child, reintegration and non- 
discrimination appear to be compromised by increasing powers of DNA collection and retention.

\section{The principle of best interests}

In its 2007 General Comment, the Committee on the Rights of the Child clarified the leading principles for the operation of an internationally compliant youth justice system. Article 3 of the Convention on the Rights of the Child (CRC) is central. It requires that the best interests of the young person be a primary consideration in all actions and proceedings concerning young people. States have varying legislative approaches to this principle. It is expressly referred to in the Children (Scotland) Act 1995, but, the paramountcy accorded to welfare may now be overridden to protect the public from serious harm (s. 16(5)). The New Zealand legislation (s. 6, CYPF Act) excepts youth justice proceedings from the principle of paramountcy, but requires that measures should seek to promote the welfare of the young person (s. 5(c)). It is questionable whether retaining genetic material from young people accords with or contributes to the principle of best interests, given the potential for stigmatisation and labelling (Becker, 1963; Lemert, 1967; Campbell, 2010a). While the storage of young people's DNA after conviction has been held not to breach the ECHR (Wv The Netherlands, Application no. 20689/08, 20 January 2009), in S and Marper v United Kingdom the Grand Chamber of the European Court of Human Rights noted 'the risk of stigmatization' in treating persons who have not been convicted in the same way as convicted persons by retaining their DNA ((2009) 48 EHRR 50 [122]). It may well be claimed, as the UK Government did in $S$ and Marper ([94]), that the absence of public articulation of suspicion means that there is no stigma in DNA retention. In response, the Grand Chamber acknowledged the applicants' 'perception that they are not being treated as innocent' ([122]). The conception of stigma here is not equivalent to discriminatory treatment per se, but rather the official labelling of certain people as potentially criminal. Although it could be said that the stigma of DNA retention is overstated on the basis that an individual would need to divulge his or her being on the database for anyone to know, internalisation of a stigmatic label occurs by virtue of his or her treatment by the State. Moreover, it is not inconceivable that a State official or leaked document could reveal a person's inclusion in the database, thereby compounding the stigma. Nevertheless, public 
communication should not be seen a pre-requisite for someone to be stigmatised by the State. While DNA retention may appear of less consequence than the maintenance of criminal records, say, the former may be more problematic in that it is not predicated on a criminal finding of guilt. In other words, there is a formalised entrenchment of a category of suspects who may be subject to increased State intervention because of partial or other DNA matches, all based on prior suspicion which led to the initial arrest.

A strong argument for the use of DNA databases is public safety, and this has been used in political quarters to justify the retention of non-convicted persons' DNA (Scottish Government, 2008, Ministry of Justice, 2009; New Zealand Police Association, 2008). Indeed, in Scotland, responses to the Fraser Report indicated that in certain instances the seriousness of the offence and the protection of the public could justify the taking and retaining of DNA samples from young people (Association of Chief Police Officers in Scotland, 2008). However, caution was urged by the Scottish Children's Reporter Administration which recommended a separate judicial process to determine whether there is a clear and justifiable reason for retention, and the office of Scotland's Commissioner for Children and Young People argued that automatic retention would be 'disproportionate' and that a sheriff should be required to approve retention based only on the risk that a particular young person poses to public safety (see Justice Committee, 2009: [365]-[366]). Despite the imperative of public protection, it is clear that different considerations should be at play when young persons are involved, given the need to safeguard their interests in light of their vulnerability and stage of development. Granted, Article 3 of the CRC does not require that the best interests of the young person override all other concerns: as Detrick (1999: 91) states the best interests of the young person are a consideration of 'first importance among other considerations, but that they do not have absolute priority above other considerations'. For Alston (1994: 13), the use of the phrase 'a primary consideration' rather than 'the primary consideration' means that the best interests standard has not been rejected completely but rather it permits a certain flexibility that would allow other people's interests (in this context, the victim of the offence or the public interest) to prevail in certain extreme cases. International standards encourage an approach centred on the re-integration of the young person and the 
promotion of the young person's wellbeing. In seeking to incorporate the traditional goals of criminal justice like public safety the Committee on the Rights of the Child has stated that a non-strictly punitive approach can be introduced 'in concert with public safety' (2007: 4b) but is then silent on how this latter imperative can be ensured. How does this somewhat murky international position apply to the question of DNA powers? There may be a basis for the retention of DNA from young people who have been found to have committed an offence of serious interpersonal violence, particularly serious sexual offending, where there is evidence of propensity to recidivism, and thus a significant threat to public safety. But, retention in lesser offences, particularly minor property offences, and in the case of unconvicted young people is problematic, when the potentially negative effects of labelling and stigmatisation are considered.

\section{Reintegration}

Reintegration of the young offender to society should be one of the principal goals of a modern and progressive youth justice system. The CRC speaks of the 'desirability of promoting the child's reintegration and the child's assuming a constructive role in society' (Article 40.1, CRC). International standards emphasise the importance of diverting young people from formal judicial proceedings to lessen the harmful effects of such processes, such as stigmatisation (Committee on the Rights of the Child, 2007). Indeed measures like the Scottish CHS and the New Zealand model of diversion and conferencing were specifically designed to divert young people from the stigmatisation of formal justice procedures (particularly pleas, trial and convictions).

In Scotland, the CHS does not determine a criminal charge when dealing with offence grounds for referral, therefore young people involved in this process have not been convicted and do not enjoy complete Article 6 rights which protect the right to a fair trial $(S$ $v$ Miller 2001 SC 977). Yet the retention of their data essentially equates them with convicted criminals. In $S$ and Marper $v$ United Kingdom the Court noted that the retention of unconvicted persons' data may be especially harmful in the case of minors 'given their special situation and the importance of their development and integration in society' ((2009) 48 EHRR 50[124]). As previously noted, the inclusion of young people's 
DNA in databases, even for a limited period, may lead to stigmatisation and to the labelling of the young person as a criminal. Utilising the finding of the supposedly welfare-based CHS to justify the retention of DNA appears a dishonest means of subsuming young people into the criminal justice system and crime control mechanisms of the State by storing their genetic material with that of convicted adults. As more serious alleged offences by young people are dealt with through the criminal courts in Scotland, it is curious that the 2010 Act extends the scope of the database to encompass young people who have committed serious offences but who are sought to be dealt with in a measured and holistic way in the CHS. In essence, these measures appear contrary to the notions of diversion and nonstigmatisation, and may alter the nature of the CHS, suggesting a closer nexus between its work and that of the criminal courts.

Similar considerations arise in New Zealand. The youth justice FGC (a statutory but informal process where the young person accused of a criminal offence, his or her family, the police, the victim and others meet to discuss responses to offending by that young person) is used at all stages of the system, and frequently in relation to serious offences (Morris and Maxwell, 2006). The FGC aims to encourage the acceptance of responsibility by the young person, the promotion of reconciliation between offender and victim, and to dispose of the offence in a restorative and constructive manner (Lynch, 2007). An important reward for the young person is the availability of discharge under section 282 of the CYPF Act. If the young person completes his or her agreed plan successfully, he or she will generally be given such a discharge, meaning no formal order or record. Nearly half of young people dealt with by the Youth Court receive such an order (Ministry of Justice, 2010). This harmonises with the precepts of restorative justice - that the young person has repaired the harm and is now free to get on with his or her life (Morris and Maxwell, 2006). In line with international standards (Committee on the Rights of the Child, 2007), it also allows the young person to avoid the stigmatisation and labelling effects of a criminal record. Yet, the recent amendments permit DNA profiles to be retained for a period of four years following a section 282 discharge. This is at odds with the principle of reintegration, as it maintains a formalised link between the young person, his or her genetic material and the crime control agents of the state, and denotes state suspicion of the young person. 


\section{Non-discrimination}

The Committee on the Rights of the Child (2007) has identified non-discrimination as a leading principle of a CRC-compliant youth justice system. A troubling aspect of DNA collection is the differential in terms of police intervention based on ethnic identification and socio-economic class (Penna and Kirby, 2009). As DNA may be taken upon arrest in Scotland and arrest/intention to charge in New Zealand, any racial or other disparity at this stage implies that incursions on personal privacy and bodily integrity will be borne disproportionately by certain societal groups. In the UK, $30 \%$ of black men compared with approximately $10 \%$ of Asian and white men have their DNA stored on the NDNAD (Equality and Human Rights Commission, 2009:29) and about three-quarters of all black men aged 16 to 34 in the UK are included in the database (Select Committee on Home Affairs, 2007: [33]). Ethnic appearance is not included in the data submitted from Scotland to the NDNAD, and thus it is not clear whether such patterns are replicated there. However, research indicates that the police are more likely to refer to the CHS young people from poor areas in general (McAra and McVie 2007: 326), suggesting the potential for bias in the Scottish database also. Discrimination is also a particular issue in New Zealand, where Māori are over-represented in the justice statistics. Māori 10-13 year olds are five times more likely and 14-16 year olds three times more likely to be apprehended by the police than European or Pacific young people (Ministry of Justice, 2010). When police discretion is used at various stages of the system, it is evident that it is used to the detriment of Māori. The New Zealand Department of Corrections (2007) described these processes variously, as the 'unintended consequences of discretion', 'unevenness of decision-making', 'bias' and 'institutional racism'. This bias at the point of arrest cannot but lead to uneven exercise of DNA powers. Further, specific cultural issues arise for Māori to whom bodily integrity and particularly blood has a special significance and power (Mead, 2003; Allan et al, 2008). This may mean that the non-consensual collection of a bodily sample will affect the young person more deeply.

Given the potential for discrimination when DNA is collected disproportionately from ethnic minorities, it is vital measures are taken to reduce discriminatory outcomes. The 
Committee on the Rights of the Child (2007) recommends that police officers should be trained in cultural sensitivity. Ostensibly the easiest way of resolving the problem of discrimination would be to create a 'universal' database (Kaye and Smith, 2004, Sedley, 2005) which would, by definition, avoid the bias in selective DNA collection and retention. Though strict regulation and governance could mitigate privacy concerns in terms of data control, such mass surveillance would represent a fundamental shift in our liberal democracy, ideologically speaking. Such a crime control mechanism would run contrary to the prevailing political principles of limited state intervention and shift the ethos of the criminal justice system dramatically. It would be a disproportionate means of crime control, and a disproportionate reaction to concerns about discrimination which are more appropriately dealt with by limiting rather than expanding the scope of the database. Moreover, in a practical sense, a universal scheme would entail huge financial costs to establish, maintain, search and safeguard. Thus, limited schemes for DNA collections, monitoring of arrest practices and improved police training are preferable means of addressing bias in this context.

\section{Conclusion}

This article has focused on New Zealand and Scotland to illustrate how expanded powers to collect and retain DNA compromise the rights of the young person and sit uneasily with key paradigms of youth justice such as best interests, reintegration and non-discrimination. There is no doubt that DNA is a valuable tool in criminal investigations, and that retention of DNA on databases has the potential to improve public safety, particularly where recividist offenders are concerned. However any use of DNA powers raises questions about balancing of rights between the suspect/offender and the public interest, and particular questions arise when young suspects and offenders are involved. The goal of reintegration requires that potentially stigmatising processes like DNA powers are used carefully, and must be justified, usually on the grounds of public safety. This is difficult to justify for minor offences and in relation to unconvicted young people. Further, the invasive nature of DNA collection and retention raises questions of appropriate rights and protections for immature and vulnerable young persons. Diversionary processes in youth justice rightly 
promote informality. In the course of this, adherence to due process standards may loosen. When longer term consequences such as DNA retention hinge on such processes, it is vital to ensure that admissions are sound, and that the young person has received appropriate legal advice.

In a wider sense, the consideration of DNA powers demonstrates the difficulties which once progressive jurisdictions face in balancing the rights of victims and the public interest with the best interests of the young person. It is a question which becomes progressively more important and pressing as the 'responsibilisation' of young people increases and the drive for crime control subsumes protective standards and norms.

\section{Notes}

1. We use the term young person to describe the clientele of the youth justice system in both jurisdictions.

2. In England and Wales a non-intimate sample (from which a DNA sample or profile may be generated) may be taken without consent from a person, whether adult or young person, who has been charged with, informed that he will be reported for, or convicted of a recordable offence, and indefinite retention of samples is permitted (PACE, s.64, as amended by the Criminal Justice and Police Act 2001).

3. See ss.62 and 63 of the Police and Criminal Evidence Act 1984. Section 65 states that an 'intimate sample' means a sample of blood, semen or any other tissue fluid, urine, saliva or pubic hair, or a swab taken from a person's body orifice, while a 'nonintimate sample' means a sample of hair other than pubic hair, a sample taken from or from under a nail, a swab taken from any part of a person's body other than a body orifice, or a footprint or a similar impression of any part of a person's body other than a part of his hand. Section 58 of the Criminal Justice and Public Order Act 1994 reclassified a swab from the mouth as a non-intimate sample which therefore does not require consent and does not need to be taken by a health care professional.

4. A recordable offence is one which carries the possibility of a custodial sentence as well as other, non-imprisonable offences in the Schedule to the National Police Records (Recordable Offences) (Amendment) Regulations 2005 (SI 2005/3106).

5. Following $S$ and Marper the Secretary of the State for the Home Department announced that the DNA of children under the age of 10 would be removed from the NDNAD immediately (National Policing Improvement Agency, 2009, 21). The Bill as it stands at time of writing (May 2011) permits non-conviction DNA retention for three years after arrest for certain serious offences, this may be extended for two years on application to the Magistrates' Court, and appeal against this decision is 
permitted to the Crown Court (Police and Criminal Evidence Act 1984, s.63F as inserted by the Protection of Freedoms Bill 2011). Although material may be retained pending investigation or proceedings, it must be deleted after acquittal or dropping of proceedings for minor offences (s.63E as inserted by the 2011 Bill). A person under the age of 18 who is convicted for the fist time of a minor offence and sentenced to less than five years may have is DNA retained until the end of that sentence plus five years (s63J).

\section{References}

Allan C, Bedford K, Buckleton J, Hudson L and Stuart K (2008) The impact of Māori cultural values on forensic science practice in New Zealand. Journal of Forensic Sciences 53 (2): 380383.

Alston P (1994) The best interests principle: towards a reconciliation of culture and human rights. In: Alston P. (Ed.) The Best Interests of the Child: Reconciling Culture and Human Rights. Oxford: Clarendon Press, 1-25.

Association of Chief Police Officers in Scotland (2008) Consultation on Retention of DNA and Fingerprint Data in Scotland. Accessed at:

http://www.scotland.gov.uk/Resource/Doc/260312/0077472.pdf

Becker H (1963) Outsiders: Studies in the Sociology of Deviance. New York: The Free Press.

Brookman F, Pierpoint H (2003) Access to legal advice for young suspects and remand prisoners. The Howard Journal of Criminal Justice 42(5): 452-470.

Campbell L (2010a) A rights-based analysis of DNA retention: 'non-conviction' databases and the liberal state. Criminal Law Review: 889-906.

Campbell L (2010b) The Scottish DNA Database and the Criminal Justice and Licensing (Scotland) Bill. Edinburgh Law Review 14(2): 290-294.

Campbell L (2010c) DNA databases and innocent persons: lessons from Scotland? Juridical Review 4: 285-296.

Campbell L (2011) 'Non-Conviction' DNA Databases and Criminal Justice: A Comparative Analysis. Journal of Commonwealth Criminal Law 1: 55-77.

Cram, I G and Walker C (1990) D.N.A. profiling and police powers Criminal Law Review 479493

Croall H (2005) Criminal justice in the devolved Scotland. In: Mooney, G. and Scott, G. (Eds.) Exploring Social Policy in the 'New' Scotland. Bristol: Policy Press, 177-199. 
Committee on the Rights of the Child (2007) General Comment No. 10: Children's rights in juvenile justice, $\mathrm{CRC} / \mathrm{C} / \mathrm{GC} / 10$.

Committee on the Rights of the Child (2011) Concluding Observations of the Committee on the Rights of the Child, New Zealand. U.N. Doc. CRC/C/NZL/3-4 (2011).

Detrick S (1999) A Commentary on the United Nations Convention on the Rights of the Child. Dordrecht: Martinus Nijhoff Publishers.

Department of Corrections (2007) Over-representation of Māori in the Criminal Justice System: An Exploratory Report. Wellington: Department of Corrections.

Equality and Human Rights Commission (2009) Police and Racism: What has been achieved 10 years after the Stephen Lawrence Inquiry report? Accessed at:

http://www.equalityhumanrights.com/uploaded_files/raceinbritain/policeandracism.pdf .

Fraser J (2008) Acquisition and Retention of DNA and Fingerprint Data in Scotland. Accessed at: http://www.sipr.ac.uk/downloads/Fraser_DNA_Report.pdf

Goldson B (Ed.) (2000) The New Youth Justice. Dorset: Russell House Publishing.

Goldson, B (2002) 'New Punitiveness: The Politics of Child Incarceration', in J Muncie, G Hughes and E McLaughlin (Eds.) Youth Justice: Critical Readings. London: SAGE.

Johnson P and Williams R (2004) DNA and criminal investigation: Scotland and the UK National DNA Database. Scottish Journal of Criminal Justice Studies 10: 71-84.

Jones T and Newburn T (2002) Learning from Uncle Sam? Understanding US influences over UK crime control policy. Governance 15 (1): 97-119.

Justice Committee (2009), 18th Report, (Session 3) Stage 1 Report on the Criminal Justice and Licensing (Scotland) Bill.

Kaye D and Smith M (2004) DNA Databases for Law Enforcement: The Coverage Question and the Case for a Population-Wide Database, in Lazer D (Ed.) DNA and the Criminal Justice System: The Technology of Justice at 225. Massachusetts Institute of Technology Press.

Kemp V, Pleasence P and Balmer NJ (2011) Children, Young People and Requests for Police Station Legal Advice: 25 years on from PACE. Youth Justice 11(2): 28-46

Key J (2008) A Fresh Start for New Zealand: A State of the Nation Speech. Accessed at: http://www.national.org.nz/Article.aspx?articleId=11772. 
Kilbrandon, Lord (1964) Children and Young Persons Scotland. Report by the Committee by the Secretary of State for Scotland by Command of Her Majesty. Edinburgh: Her Majesty's Stationery Office.

Lemert E (1967) Human Deviance, Social Problems and Social Control. New York: Prentice Hall.

Lynch N (2007) Respecting Legal Rights in the New Zealand Youth Justice Family Group Conference. Current Issues in Criminal Justice 19(1):75-89.

Lynch N (2008) 'Youth Justice in New Zealand: A Children's Rights Perspective. Youth Justice 8(3): 215-229.

Lynch N (2010a) Restorative Justice Through a Children's Rights Lens. International Journal of Children's Rights 18(1): 161-183.

Lynch N (2010b) Changes to Youth Justice. New Zealand Law Journal: 121-160

Lynch N (2010c) A change in the law for child offenders: the Children, Young Persons, and Their Families (Youth Courts Jurisdiction and Orders) Amendment Act 2010. New Zealand Family Law Journal 6(10): 289-293.

McAra L (2008a) Welfare in crisis? Key developments in Scottish youth justice. In: Muncie J and Goldson B (eds) Comparative Youth Justice: Critical Issues. London: Sage Publications, 127-145.

McAra L (2008b) Crime, criminology and criminal justice in Scotland. European Journal of Criminology 5(4): 481-504.

McAra L and McVie S (2007) Youth justice? The impact of system contact on patterns of desistance from offending. European Journal of Criminology 4 (3): 315-345.

McDiarmid C(2001) Perspectives on the children's hearings system. In: Scoular J (Ed.) Family Dynamics: Contemporary Issues in Family Law. London: Butterworths, 29 - 48.

McLaren K (2002). Tough is Not Enough: Getting Smart About Youth Crime. Wellington: Ministry of Youth Affairs.

Ministry of Justice (2009) Criminal Investigations (Bodily Samples) Amendment Bill Regulatory Impact Statement. Wellington: Ministry of Justice.

Ministry of Justice (2010) Child and Youth Offending Statistics in New Zealand: 1992 to 2008. Wellington: Ministry of Justice.

Mead S (2003)Tikanga Mãori: living by Mãori values. Wellington: Huia. 
Morris A and Maxwell G (Eds) (2001) Restoring Justice for Juveniles: Conferencing, Mediation and Circles. Oxford: Hart Publishing.

Morris A and Maxwell G (2006) Youth justice in New Zealand: restorative justice in practice? Journal of Social Issues 62( 2): 239-258.

Muncie J (2005) The globalisation of crime control - the case of youth and juvenile justice. Theoretical Criminology 9(1): 35-64.

Muncie J (2008) The 'Punitive Turn' in Juvenile Justice: Cultures of Control and Rights Compliance in Western Europe and the USA. Youth Justice 8(2): 107-121.

National Policing Improvement Agency (2009) National DNA Database Annual Report 2007 - 2009. Accessed at: http://www.npia.police.uk/en/14395.htm.

National Policing Improvement Agency (2010) Statistics. Accessed at: http://www.npia.police.uk/en/13338.htm

New Zealand Police (2010) Annual Report for the Year Ended 30 June 2010. Accessed at: http://www.police.govt.nz/annual-report-2010.

Nuffield Council on Bioethics (2007) The Forensic Use of Bioinformation: Ethical Issues. Accessed at: http://www.nuffieldbioethics.org/bioinformation.

Parliamentary Question S3W-31255 - James Kelly (Glasgow Rutherglen) (Lab) (Date Lodged Friday, January 29, 2010); Answered by Kenny MacAskill (Tuesday, February 09, 2010).

Parliamentary Office of Science and Technology (2006) PostNote: February 2006. Accessed at: http://www.parliament.uk/documents/post/postpn258.pdf.

Penna S and Kirby S (2009) Children and the 'new biopolitics of control': identification, identity and social order. Youth Justice 9(2): 143-156.

Piacentini L and Walters R (2006) The politicisation of youth crime in Scotland and the rise of the Burberry court. Youth Justice 6(1): 43-59.

Pratt J (2008) When penal populism stops: legitimacy, scandal and the power to punish in New Zealand. Australian and New Zealand Journal of Criminology 41( 3): 364-383.

Pratt J and Clark M (2005) Penal populism in New Zealand. Punishment and Society 7 (3): 303-320.

Jackson J and Quinn K (2007). Police Interviews with Young Suspects in Northern Ireland. British Journal of Criminology. 47:234-255. 
Redmayne M (1995) Doubts and burdens: DNA evidence, probability and the courts. Criminal Law Review 464-482.

Scottish Government (2008) Fraser Report on Retention of DNA and fingerprint data Government's response, Consultation on the Acquisition and Retention of DNA and Fingerprint Data in Scotland (CRES 1058). Accessed at:

http://www.scotland.gov.uk/Resource/Doc/239066/0065846.pdf

Scottish Government (2009) Acquisition and Retention of DNA and Fingerprint Data in Scotland. Consultation Report. Accessed at:

http://www.scotland.gov.uk/Publications/2009/02/24104443/7

Select Committee on Home Affairs (2007) Second Report, Session 2006-07

Simon J (1995) They Died with Their Boots On: The Boot Camp and the Limits of Modern Penality', Social Justice 22(1): 25-48.

Sedley S (2005) Short Cuts London Review of Books 27(5): 24-25.

Steinberg L and Scott E (2003) Less Guilty by Reason of Adolescence Developmental Immaturity, Diminished Responsibility, and the Juvenile Death Penalty, American Psychologist 58(12): 1009-1018.

\section{Cases}

Wv The Netherlands, Application no. 20689/08, 20 January 2009

$S$ and Marper $v$ United Kingdom (2009) 48 EHRR 50

S v Miller 2001 SC 977

Liz Campbell is a Senior Lecturer, School of Law, University of Aberdeen, Scotland. liz.campbell@abdn.ac.uk

Nessa Lynch is a Lecturer, Faculty of Law, Victoria University of Wellington, New Zealand. Nessa.lynch@vuw.ac.nz. My thanks to Kiritapu Allan, Emily Bruce and James Gilbert for research assistance.

Our thanks to Ursula Kilkelly for helpful comments on a previous draft. All errors remain our own. 
